\title{
Morbidity of School Children in Panauti Municipality of Kavrepalanchowk: A Descriptive Cross-sectional Study
}

\author{
Naresh Manandhar, ${ }^{1}$ Pratiksha Pathak, ${ }^{1}$ Prasanna Lama, ${ }^{1}$ Sunil Kumar Joshi ${ }^{1}$ \\ 'Department of Community Medicine, Kathmandu Medical College, Sinamangal, Kathmandu, Nepal.
}

\section{ABSTRACT}

Introduction: School health has been considered as a high priority intervention in developing countries but it has not been prioritized in Nepal. The objectives of the study are to find out the prevalence of morbidity and nutritional status in school children.

Methods: A descriptive cross-sectional study was conducted in a private school located at Panauti Municipality of Kavrepalanchowk district for one week of November 2019. A convenient sampling technique was used. From a selected school, a total number of 356 students studying from Grade I to $X$ were included in the study using. Confidence Interval at $95 \%$ was calculated along with frequency and proportion for binary data using Statistical Package for Social Science (SPSS) software.

Results: Among 356 students, the most common three morbidities were dental caries $43(18.1 \%)$, tonsillitis $26(6.2 \%)$, and headache 18 (7.1\%). Based on weight for age, $43(23.9 \%)$ boys and $22(12.5 \%)$ girls were underweight and $12(6.7 \%)$ boys and $4(2.7 \%)$ girls were overweight and $6(2 \%)$ were obese. Thus school health programs should give more emphasis on oral health, nutrition, personal hygiene, etc.

Conclusions: The health and nutritional status of school children in this study were found to be satisfactory compared to other studies. The present study emphasized oral health. The school health program is important in the school for the prevention of diseases like a parasitic infestation, improving personal hygiene, and nutritional status.

Keywords: body mass index; dental caries; morbidity; nutritional status; underweight.

\section{INTRODUCTION}

World Health Organization's Global School Health Initiative, seeks to mobilize and strengthen health promotion and education activities at the local, national, regional and global levels. The Initiative is designed to improve the health of students, school personnel, families and other members of the community through schools. ${ }^{1}$ In 1997, WHO developed 10 recommendations for school health, and initiated a global school health initiative in ten countries, of which 8 were developing countries. ${ }^{1}$ School health program has included essential components of public health for cost-effective health program, the nutrition, and health of school children. Ne- pal's poverty was $21 \%$ in $2018 .^{2}$ Poor people are more likely to be affected by different forms of malnutrition. Malnutrition increases health care costs, reduces productivity and slows economic growth, which can perpetuate a cycle of poverty and ill health. ${ }^{3}$

The objectives of the study are to find out the prevalence of morbidity and nutritional status in school children.

Correspondence: Dr. Naresh Manandhar, Department of Community Medicine, Kathmandu Medical College, Sinamangal. Kathmandu. Email: nareshsayami@yahoo.com, Phone: +977-9841500281. 


\section{METHODS}

A descriptive cross-sectional study was conducted in a school of Panauti Municipality, Kavrepalanchowk district for 10th to 15th November 2019. Ethical approval was taken from the Institutional Review Committee of Kathmandu Medical College. The purpose of the study was explained to the school Principal and permission was taken from the Principal and parents of students to conduct the study. Students studying from grade I to $X$ were taken into the study. Those who were absent or were not willing to participate were excluded from the study.

The structured questionnaire was developed. The questionnaire consisted of demographic information, physical and clinical examination. The instruments used were a weighing machine and measuring tape. Each child's weight was measured in kilograms. The scale was calibrated against known weight regularly. Zero error was checked for and removed every day if present. Students wore only light clothes while measuring weight in the classroom. The weights were recorded to the nearest $100 \mathrm{~g}$. Height in centimeters was marked on the wall in school with the help of a measuring tape. The students were asked to remove their shoes and stand with heels together and head positioned in such a way that the line of vision was perpendicular to the body. A scale was brought down to the topmost point on the head of students standing against the wall where the calibration was done. The height was measured to the nearest $0.5 \mathrm{~cm}$. Health Examination of all students underwent a thorough physical and systemic examination including medical history. The Convenient sampling technique was used. Selection bias and measurement bias has been addressed as far as possible.

Collected data were entered into Microsoft Excel. Data analysis was done using SPSS version 20. Frequency and percentage were calculated. BMI for age was computed using Group BMI Calculator, Metric, v1.0-CDC.

\section{RESULTS}

Out of 356 students, the morbidity was present in $101(28.37 \%)$ school children, commonest was Dental caries $42(11.08 \%)$, and followed by Tonsillitis 26 (7.3\%). Headache and Eye problems were found to be $18(5.06 \%)$ and $17(4.78 \%)$ school children respectively. The morbidities were found higher in boys compared to girls except for ear problems (Table 1).

\begin{tabular}{|c|c|c|c|c|}
\hline S.N. & Morbidities & $\begin{array}{l}\text { Boys } \\
\text { n (\%) }\end{array}$ & $\begin{array}{l}\text { Girls } \\
\text { n (\%) }\end{array}$ & $\begin{array}{l}\text { Total } \\
\text { n (\%) }\end{array}$ \\
\hline 1 & $\begin{array}{l}\text { Dental } \\
\text { caries }\end{array}$ & $\begin{array}{l}22 \\
(12.22)\end{array}$ & $\begin{array}{l}21 \\
(11.93)\end{array}$ & $\begin{array}{l}43 \\
(12.08)\end{array}$ \\
\hline 2 & Tonsillitis & $14(7.78)$ & $\begin{array}{l}12 \\
(6.82)\end{array}$ & $\begin{array}{l}26 \\
(7.30)\end{array}$ \\
\hline 3 & Headache & $10(5.56)$ & $8(4.55)$ & $\begin{array}{l}18 \\
(5.06)\end{array}$ \\
\hline 4 & $\begin{array}{l}\text { Refractive } \\
\text { error }\end{array}$ & $10(5.56)$ & $7(3.98)$ & $\begin{array}{l}17 \\
(4.78)\end{array}$ \\
\hline 5 & $\begin{array}{l}\text { Ear prob- } \\
\text { lem }\end{array}$ & $2(1.11)$ & $6(3.41)$ & $8(2.25)$ \\
\hline 6 & $\begin{array}{l}\text { Skin prob- } \\
\text { lem }\end{array}$ & $4(2.22)$ & $2(1.14)$ & $6(1.69)$ \\
\hline 7 & Gastritis & $3(1.67)$ & $1(0.57)$ & $4(1.13)$ \\
\hline 8 & $\begin{array}{l}\text { Abdomen } \\
\text { pain }\end{array}$ & - & $4(2.28)$ & $4(1.13)$ \\
\hline
\end{tabular}

There were 180 (50.6\%) boys and 176 (49.4\%) girls included in the study. The mean age of students was $11.38 \pm 2.83$ years. The age of the students ranged from 6 to 17 years (Table 2). The majority of them were between the ages of 11 to 15 years.

\begin{tabular}{|c|c|c|c|}
\hline \multirow[t]{2}{*}{$\begin{array}{c}\text { Age } \\
\text { (years) }\end{array}$} & \multicolumn{2}{|c|}{ Sex } & \multirow{2}{*}{$\begin{array}{l}\text { Total } \\
\text { n (\%) }\end{array}$} \\
\hline & Boys n (\%) & Girls n (\%) & \\
\hline 6 & $9(50.0)$ & $9(50.0)$ & $18(5.1)$ \\
\hline 7 & $15(51.7)$ & $14(48.3)$ & $29(8.1)$ \\
\hline 8 & $10(55.6)$ & $8(44.4)$ & $18(5.1)$ \\
\hline 9 & $12(38.7)$ & 19 (61.3) & $31(8.7)$ \\
\hline 10 & $25(73.5)$ & $9(26.5)$ & $34(9.6)$ \\
\hline 11 & $19(46.3)$ & $22(53.7)$ & $41(11.5)$ \\
\hline 12 & $17(37.8)$ & $28(62.2)$ & $45(12.6)$ \\
\hline 13 & $31(60.8)$ & $20(39.2)$ & $51(14.3)$ \\
\hline 14 & $18(47.4)$ & $20(52.6)$ & $38(10.7)$ \\
\hline 15 & 11 (37.9) & $18(62.1)$ & $29(8.1)$ \\
\hline 16 & 9 (52.9) & $8(47.1)$ & $17(4.8)$ \\
\hline 17 & $4(80.0)$ & $1(20.0)$ & $5(1.4)$ \\
\hline Total & $180(50.6)$ & $176(49.4)$ & $356(100.0)$ \\
\hline
\end{tabular}

The mean and standard deviation of height, weight, and Body Mass Index (BMI) were $1.40 \mathrm{~m} \pm 0.16 \mathrm{~m}, 33.82$ $\mathrm{kg} \pm 12.01 \mathrm{~kg}$ and $16.53 \mathrm{~kg} / \mathrm{m} 2 \pm 2.98 \mathrm{~kg} / \mathrm{m} 2$ respec- 
tively. The proportion of school children with normal BMI was 269 (76\%), out of which 124 (68.9\%) were boys and $145(82.4 \%)$ were girls. Sixteen $(4.5 \%)$ of the students were overweight, $12(6.7 \%)$ were boys. Under the obese category, there were $6(1.7 \%)$ students in which $5(2.8 \%)$ were boys (Table 3$)$.

\begin{tabular}{|c|c|c|c|}
\hline Label & $\begin{array}{l}\text { Boys } \\
\text { n (\%) }\end{array}$ & $\begin{array}{l}\text { Girls } \\
\text { n (\%) }\end{array}$ & $\begin{array}{l}\text { Total } \\
\text { n (\%) }\end{array}$ \\
\hline Underweight & $43(23.9)$ & $22(12.5)$ & 65 (18.3) \\
\hline $\begin{array}{l}\text { Normal BMI (5th - } \\
\text { 85th Percentile) }\end{array}$ & $124(68.9)$ & $145(82.4)$ & 269 (75.6) \\
\hline $\begin{array}{l}\text { Overweight or } \\
\text { obese ( } \geq 85 \text { th } \\
\text { Percentile) }\end{array}$ & $12(6.7)$ & $4(2.7)$ & $16(4.5)$ \\
\hline $\begin{array}{l}\text { Obese ( } \geq 95 \text { th Per- } \\
\text { centile) }\end{array}$ & $5(2.8)$ & $1(0.6)$ & $6(1.7)$ \\
\hline
\end{tabular}

\section{DISCUSSION}

The present study was carried out to find out the morbidity patterns of the school children. School health survey gives a good chance to screen a large number of school children with minimum resources. In present study dental caries was found in $11.08 \%$, followed by Tonsillitis 7.3\%, Headache $5.06 \%$ and Eye problem $4.78 \%$. The survey conducted by Shrestha et al. in Pokhara, found the prevalence of dental caries $(41.5 \%)$, worm infestation $(33.7 \%)$ and pediculosis $(32.6 \%)$ in both sexes in six governmental primary school. ${ }^{4}$ The study conducted by Gokhale et al. found that the most common morbidities were dental caries (61.1\%) followed by ear wax (38.1\%), URTI (19\%) and Ear discharge (13.5\%). ${ }^{5}$ The study conducted by Mayavati et al. observed dental caries $(65.1 \%)$, upper respiratory tract infections $(38.2 \%)$, ear wax $(29.9 \%)$ and myopia $(10.0 \%)$ in urban school children. ${ }^{6}$ A study conducted in Madhya Pradesh, India by Shinde reported that $31.83 \%$ were having morbidity associated with dental carries followed by anemia $(15.69 \%)$, vitamin A deficiency $(6.25 \%)$, worm infestation $(4.94 \%)$, scabies $(4.06 \%)$, URI $(3.77 \%)$, defective vision $(0.58 \%)$, conjunctivitis $(0.44 \%)$ and congenital malformation $(0.15 \%){ }^{7}$ A study conducted by Bhandari et al. in Kavrepalanchowk district reported pediculosis $42(26.2 \%)$, dental caries 29 (18.1\%), and waxy ear $27(17.1 \%)$ were three major morbidity in school children. ${ }^{8}$ Syed et al. conducted the study in Hyderabad, India found most common morbidities were Dental caries (56.24\%), anemia (33.8\%), worm infestation (48.25\%) and Refractive error (11.22\%). ${ }^{9}$ Kalyani et al. found most common morbidities were anemia (40\%), Dental caries (61.6\%), and pediculosis (40\%). URT infection (32.8\%) Refractive error (4\%). ${ }^{10}$
These results were higher than that of the present study findings where dental caries was $11.08 \%$, followed by Tonsillitis 7.3\%, Headache $5.06 \%$ and Eye problem $4.78 \%$. These differences may be due to the fact that the present study conducted in only a private school and improving health status as change with time period. The present study results were consistent with a study conducted by Pandey et al, ${ }^{11}$ Kausar et al, ${ }^{12}$ Shakya et al. ${ }^{13}$

In the World, the prevalence of malnutrition in term of Underweight, stunting and wasting are $27 \%, 31 \%$ and $10 \%$ respectively. ${ }^{14}$ In Nepal, more than $80 \%$ of the population lives in villages. Nepal Demographic and Health Survey, 2016 reported that $27 \%$ of children under 5 years were underweight, and $5 \%$ were severely underweight. The proportion of children who were underweight was greater in rural areas (31\%) than urban areas $(23 \%)$. Children of mothers with no education were more than twice as likely to be underweight as children whose mothers were educated up to SLC level. Underweight was inversely related to wealth quintile; $33 \%$ of children in the lowest wealth quintile were underweight, as compared with $12 \%$ of children in the highest quintile. $10 \%$ of children were wasted and $2 \%$ severely wasted. $36 \%$ of children were stunted, and $12 \%$ were severely stunted in Nepal (NDHS, 2017). ${ }^{15}$ A survey done by Shrestha et al found that the prevalence of wasting, stunting and malnutrition in the school children were $10.3 \%, 14.9 \%$ and $85 \%$ respectively with $31.8 \%$ of boys and $89.4 \%$ of girls students were malnourished. 4 Study conducted by Bhandari et al found that $55.3 \%$ boys and $35.8 \%$ girls fell under 1 st-degree malnutrition and $23.07 \%$ boys and $46.3 \%$ girls fell under 2nd-degree malnutrition, $7.2 \%$ girls fell under 3rd-degree malnutrition based on weight for age. ${ }^{8}$ The study conducted by Gokhale et al. found that the majority of school children $(69.8 \%)$ were normal and $7.1 \%$ were severely underweight.5 The study carried out in Sullia town, South India by Amruth et al revealed the prevalence of underweight and stunting were $26.5 \%$ and $19.2 \%$ respectively. ${ }^{16}$ The nutritional status of government school children was comparatively poorer than private school children. Boys had a higher prevalence of malnutrition than girls. These findings were consistent with the present study where $24 \%$ of children were underweight and boys were more underweight than girls.

Gokhale et al. conducted the study in Maharashtra, India found $73 \%$ children had some morbidity. A study conducted in Madhya Pradesh, India reported morbidities were present in $58.72 \%$ of school children. The present study found that morbidities were present in $28.37 \%$ school children which were lower as compared to the other studies. This difference probably may be 
due to the present study conducted in grade $I$ to $X$ of urban area and in a private school where children were from educated and well up families. Overall present health status is also improving compared to past health status.

\section{CONCLUSIONS}

Among different morbidities, dental caries was found more common. The health and nutritional status of school children were found to be satisfactory in this study compared to other studies. The present study emphasized the need for the initiation of oral health programs in schools. The study also reflects the importance of improving personal hygiene, prevention of disease like parasitic infection/infestation and improvement of their nutritional status. Today's children are the future of the country and the development of a country depends upon the development of children thus we should invest in school children.

\section{ACKNOWLEDGEMENTS}

The authors would like to thank the principal and all the respondents for providing valuable information. We also like to thank VII semester MBBS students who helped in data collection.

\section{Conflict of Interest: None.}

\section{REFERENCES}

1. World Health Organization. School and youth health. Geneva, Switzerland: WHO Prevention of Noncommunicable Diseases (PND); 1997. Global school health initiative. [Full Text]

2. Gokul Baskota. 21 percent of Nepal Population Under Poverty Line. Nepali Sansar [Internet]. 2018 September 4. Available from: https://www.nepalisansar.com/news/21percent-of-nepal-population-under-poverty-line/. [ [ Full Text]

3. World Health Organization. Malnutrition. Geneva, Switzerland: World Health Organization; 2018 Feb 16. [Full Text]

4. Shrestha L, Khattri JBK. Health status of school children of Pokhara valley, Nepal. J Nepal Med Assoc. 2003;42(147):12832. [Full Text | DOI]

5. Gokhale CN, Borgaonkar CA, Shanbhag SS, Solanki MJ, Rasal MM. Morbidity pattern among primary school children in a tribal area of Maharashtra. Int J Community Med Public Health. 2018 Jan;5(1):165-9. [Full Text | DOI]

6. Mhaske MS, Khismatrao DS, Kevin F, Pandve HT, Kundap RP. Morbidity Pattern and Personal Hygiene in Children Among Private Primary School in Urban Area: Are the Trends Changing? J Family Med Prim Care. 2013 JulSep;2(3):266-9. [PubMed | Full Text | DOI]

7. Shinde M, Joshi A, Trivedi A. Morbidity pattern among school children of rural area of Obaidullaganj block of Raisen District of Madhya Pradesh. Int J Adv Med. 2015 May;2(2):144-6 [Full Text]

8. Bhandari N, Shrestha GK. Nutritional status and morbidity pattern in school age children in Nepal. Journal of College of Medical Sciences. 2012;8(2),12-6. [․ㅏll Text | DOI]
9. Syed S, Gangam S, Syed S, Rao R. Morbidity patterns and its associated factors among school children of an urban slum in Hyderabad, India. Int J Med Sci Public Health. 2015;4(9),1277-81. [ Full Text | DOI]

10. Kalyani P, Felix AJW, Arulmani A. Morbidity pattern in school children of urban area in Tamilnadu. National Journal of Public health. April 2016;1(2):58-61. [Full Text]

11. Pandey S, Dudani I, Pradhan A. Health profile of school children in Bhaktapur. Kathmandu Univ Med J. 2005;3(11):274-80. [Full Text]

12. Kausar Hina, Sambutwad RC, Shafee Mohd. Prevalence of morbidity and morbidity pattern among primary school children in rural area of Jalna, Maharashtra, India. Int J Community Med Public Health. 2016 Jun;3(6):1623-7. [Full Text]

13. Shakya SR, Bhandary S, Pokharel PK. Nutritional status and morbidity pattern among governmental primary school children in the Eastern Nepal. Kathmandu Univ Med J. 2004;2(8):307-14. [․ pubMed | Full Text]

14. World Health Organization. Global Health Observatory (GHO) data. Geneva, Switzerland: World Health Organization; 2018. Body Mass Index (BMI). [Full Text]

15. Ministry of Health, Nepal. Nepal Demographic and Health Survey 2016. Kathmandu, Nepal: Ministry of Health; 2017. 591p. [Full Text]

16. Amruth M, Kumar S, Kulkarni AG, Kamble SV, Ismail IM. A study on nutritional status and morbidity pattern among primary school children in Sullia town, South India. Indian Journal of Basic and Applied Medical Research. 2015 September;4(4):100-12. [Full Text]

The Author(s) 2018.

This work is licensed under a Creative Commons Attribution 4.0 International License. The images or other third party material in this article are included in the article's Creative Commons license, unless indicated otherwise in the credit line; if the material is not included under the Creative Commons license, users will need to obtain permission from the license holder to reproduce the material. To view a copy of this license, visit http://creativecommons.org/licenses/by/4.0/ 